ISSN: 2224-0616

Int. J . Agril. Res. Innov. \& Tech. 4 (2): 6-10, December, 2014 Available online at http://www.ijarit.webs.com

\title{
EVALUATION OF GROWTH OF Chlorella ellipsoidea IN DIFFERENT CULTURE MEDIA
}

\author{
F. Jahan', M.S. Rahman' ${ }^{1}$ and M.A. Hossain ${ }^{2 *}$
}

Received 12 June 2014, Revised 24 October 2014, Accepted 22 December 2014, Published online 31 December 2014

\begin{abstract}
An experiment was conducted to evaluate the growth of Chlorella ellipsoidea in three different media viz,. medium I (pulse bran), medium II (soil extract) and medium III (inorganic) under the natural environmental conditions. The alga, C. ellipsoidea, reached

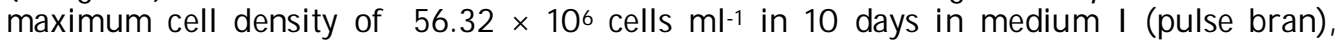
maximum cell density of $102.99 \times 10^{6}$ cells ml-1 $^{-1}$ in 11 days in medium II (soil extract) and maximum cell density of $64.23 \times 10^{6}$ cells $\mathrm{ml}^{-1}$ in 12 days in medium III (inorganic medium). The ranges of water temperature, air temperature and light intensity were 22 to $32^{\circ} \mathrm{C}, 22$ to $34^{\circ} \mathrm{C}$ and 2.11 to $4.31\left(\times 10^{3}\right)$ lux, respectively during the culture period. The average sunshine period was $7.65 \pm 1.57$ hours. Total alkalinity, free $\mathrm{CO}_{2}, \mathrm{pH}, \mathrm{NO}_{3}-\mathrm{N}, \mathrm{PO}_{4}$ $\mathrm{P}$ of algal culture medium I, medium II and medium III were 220,200 and $150 \mathrm{mg} \mathrm{L}^{-1} ; 26$, 9 and $19 \mathrm{mg} \mathrm{L}^{-1}$; 7.9, 7.6 and 7.5; 45, 45 and $133.33 \mathrm{mg} \mathrm{L}^{-1}$; 10.9, 15.1 and $37.06 \mathrm{mg} \mathrm{L}^{-1}$, respectively. Cell densities of cultures of C. ellipsoidea under three treatments I, II and III, it can be concluded that cell densities under 3 treatments are significantly different $(\mathrm{F}=39.78)$ and treatment II (soil extract medium) is the best for algal (C. ellipsoidea) culture among three treatments.
\end{abstract}

Keywords: Soil Extract, Chlorella , Culture Media, Envioronmental Factors, Chemical Quality of Media

${ }^{1}$ Department of Fisheries Management, Bangladesh Agricultural University, Mymensingh, Bangladesh

${ }^{2}$ Department of Aquaculture, Bangabandhu Sheikh Mujibur Rahman Agricultural University, Gazipur, Bangladesh

*Corresponding author's email: amzad@ bsmrau.edu.bd (M.A. Hossain)

\section{Introduction}

Microalgae, such as Chlorella are rich in nutrients especially protein, lipid and minerals (Becker, 1994a \& b; Soeder, 1980; Geldenhuys et al., 1988). A dried sample of pure Chlorella has nutrients which contain moisture $4.5 \%$, crude protein $51.8 \%$, crude fat $13.6 \%$, carbohydrate $25.2 \%$, crude fibre $2.3 \%$, crude ash $4.9 \%$, and chlorophyll $1.52 \%$. Available energy from Chlorella was $430 \mathrm{cal} \mathrm{g}^{1}$ (Tang and Suter, 2011). Chlorella contains all other essential nutrients that are needed for growth and development of both aquatic and terrestrial animals. So, people of some countries such as China and Japan have been using seaweeds and certain other algae as a source of food. Having perceived the miraculous nutritional quality of Chlorella, Japanese manufactured Chlorella tablets in the late 1950s; and from that time, numerous endeavors have emerged at specialized industries worldwide with a view to producing health food, food additives, animal feed, biofertilizers, biofuel and an assortment of natural products (Sasson, 1997; Christi, 2007). Two algae, Scenedesmus sp. and Chlorella sp. are of commercial importance due to their commercial significance of Chlorella sp. (Rydlo, 1973) which are (i) food, protein supplement/fortification in diets for malnourished children and adults; (ii) feed, protein/vitamin supplement in feed for poultry cattle, pigs, and bivalves; (iii) health food, Chlorella sp. powder as ingredients and supplement in health food recipes and products; (iv) therapeutics, $\beta$-carotene as possible anti skin-cancer treatment is used for variety of skin diseases; (v) pigments, $\beta$-carotene as food color and food supplement (provitamin A); and (vi) other uses, biofertilizers, soil conditioner, and waste treatment.

So, considering very high importance of microalgae culture, Chlorella ellipsoidea, a very important microalga, has been selected to culture in inexpensive culture media, especially soil extract, to reduce the cost of culture and to introduce easy technique of culture.

\section{Materials and Methods}

\section{Preparation of three algal culture media}

1. Preparation of inexpensive culture medium using pulse bran (masakalai bran, Vigna mungo) according to the method of Rahman (2000):

This medium was prepared by mixing $1 \mathrm{~kg}$ pulse bran (Vigna mungo) in 20-litre tap water. After a week, $15 \mathrm{~g}$ urea [ $\left(\mathrm{NH}_{2}\right)_{2} \mathrm{CO}$ ] was added into the mixture. After three weeks, pulse bran mixture 
was filtered through thin markin cloth to discard solid materials and then after several days the clear supernatant was siphoned to another bucket. To clear the medium, lime $(\mathrm{CaO})$ was added to the medium at the rate of $2 \mathrm{~g}$ per litre and after a week supernatant was siphoned to another bucket. After adding lime, $\mathrm{pH}$ of the medium increased to about 10. Then to lower the $\mathrm{pH}$ to about 7.9, conc. $\mathrm{H}_{2} \mathrm{SO}_{4}$ was added to the medium at the rate of $0.325 \mathrm{mlL}^{-1}$ and after one week, the medium was ready to be used for algae culture.

\section{Preparation of soil extract medium}

Soil (textural class, silty clay loam, pH, 7.3; organic carbon (\%), 0.95; organic matter (\%), 0.64; available phosphorous (mg L-1), 17.12; total nitrogen (\%), 0.087 was dried for 2 weeks. After drying, soil was crushed into powder to facilitate sieving. Soil was sieved through a small mesh sieve usually used to sieve rice powder for making cake. Then $2 \mathrm{~kg}$ soil was mixed with 5L tap water in a plastic bucket. Soil-water mixture was kept for 5 days and during this period, mixture was stirred everyday for half an hour. Then soil-water mixture was kept in this condition for several days untill the settling of soil particles at the bottom of the bucket. Then supernatant (soil extract) was siphoned with a plastic pipe to a plastic container. This supernatant was sterilized in an autoclave at $121^{\circ} \mathrm{C}$ temperature and $15 \mathrm{lb} /$ inch $^{2}$ pressure for 20 minutes. Then soil extract was treated with commercial urea (5 g per litre) and T.S.P ( $2.5 \mathrm{~g}$ per litre) fertilizers, this soil extract were used as algal culture medium.

\section{Preparation of inorganic medium}

Inorganic medium was prepared with the inoculation of stock solutions of 8 major nutrients $\quad\left(\mathrm{NaNO}_{3}, \quad \mathrm{MgSO}_{4} .7 \mathrm{H}_{2} \mathrm{O}, \quad \mathrm{K}_{2} \mathrm{HPO}_{4}\right.$, $\mathrm{CaCl}_{2} .2 \mathrm{H}_{2} \mathrm{O}, \mathrm{Na}_{2} \mathrm{CO}_{3}$, EDTA, Ferric ammonium citrate, Citric acid) and 6 minor nutrients $\left(\mathrm{H}_{3} \mathrm{BO}_{3}, \quad \mathrm{MnCl}_{2} \cdot 4 \mathrm{H}_{2} \mathrm{O}, \quad \mathrm{Na}_{2} \mathrm{MoO}_{4} \cdot \mathrm{H}_{2} \mathrm{O}\right.$, $\mathrm{ZnSO}_{4} .7 \mathrm{H}_{2} \mathrm{O} \quad \mathrm{CuSO}_{4} .7 \mathrm{H}_{2} \mathrm{O}, \mathrm{CaSO}_{4} .7 \mathrm{H}_{2} \mathrm{O}$ ). Ten liter distilled water was taken in a 30 litre plastic bucket and stock solutions were added and mixed well in the bucket and stored in a 15 litre plastic container. Stock solutions were prepared in distilled water using different chemical compounds as major nutrients and trace elements soil extract were used as algal culture medium

\section{Study of the environmental factors}

Water temperature, air temperature was determined by thermometer and light intensity were determined by a lux-meter (LUX-101). Data of sunshine period and rainfall were collected from the "Weather Yard" of Bangladesh Agricultural University, Mymensingh.

\section{Results}

\section{Cell densities of $\mathrm{C}$. ellipsoidea in medium I (pulse bran)}

The growth of C. ellipsoidea calculated in medium I (pulse bran) under treatment I in 4 replications in natural light and temperature conditions. Culture of these green algae, started with $0.152 \times 10^{6}$ cells ml-1 (inoculum was 5\%) which attained the maximum cell density of $56.32 \times 10^{6}$ cells $\mathrm{ml}^{-1}$ in 10 days. The average cell density of C. ellipsoidea was $28.31 \times 10^{6}$ cells ml- $^{-1}$ after the culture period of 17 days (Table 1, Fig. 1).

Table 1. Daily variation of mean cell density of C. ellipsoidea (mean of 4 replications under the treatment) cultured in medium-I (pulse bran), medium-II (soil extract), medium-III (inorganic) and environmental conditions

\begin{tabular}{|c|c|c|c|c|c|c|c|c|}
\hline $\begin{array}{c}\text { Culture } \\
\text { time (days) }\end{array}$ & $\begin{array}{c}\text { Cell density } \\
\text { Treatment I }\end{array}$ & $\begin{array}{l}\left(\times 10^{6}, \text { cells m }\right. \\
\text { Treatment II }\end{array}$ & $\begin{array}{l}-1) \\
\text { Treatment III }\end{array}$ & $\begin{array}{c}\text { Water } \\
\text { temp. }\left({ }^{\circ} \mathrm{C}\right) \\
\text { (Av.) }\end{array}$ & $\begin{array}{l}\text { Air temp. } \\
\left({ }^{\circ} \mathrm{C}\right) \text { (Av.) }\end{array}$ & $\begin{array}{c}\text { Light } \\
\text { intensity } \\
\left(\times 10^{3} \text { lux }\right)\end{array}$ & $\begin{array}{c}\text { Sunshine } \\
\text { Period* } \\
\text { (hrs.) }\end{array}$ & $\begin{array}{c}\text { Rainfall* } \\
\text { (mm) }\end{array}$ \\
\hline 1 & 3.68 & 6.4 & 2.56 & 27.00 & 30.00 & 2.50 & 6.8 & 00.0 \\
\hline 2 & 8.89 & 13.21 & 10.87 & 27.75 & 27.00 & 2.11 & 9.3 & 00.0 \\
\hline 3 & 15.09 & 18.99 & 18.32 & 27.50 & 32.50 & 2.93 & 9.2 & 00.0 \\
\hline 4 & 29.16 & 44.19 & 23.44 & 28.50 & 31.00 & 2.90 & 8.8 & 00.0 \\
\hline 5 & 32.86 & 57.76 & 27.50 & 27.50 & 29.50 & 2.53 & 8.1 & 00.0 \\
\hline 6 & 33.22 & 58.97 & 30.71 & 27.00 & 26.75 & 2.30 & 7.5 & 00.0 \\
\hline 7 & 41.7 & 63.06 & 35.87 & 26.75 & 27.50 & 4.31 & 6.5 & 0.60 \\
\hline 8 & 43.99 & 80.26 & 40.22 & 26.50 & 29.50 & 3.93 & 8.3 & 00.0 \\
\hline 9 & 46.29 & 85.02 & 46.28 & 25.00 & 28.50 & 2.90 & 9.3 & 00.0 \\
\hline 10 & 56.32 & 90.54 & 48.60 & 25.75 & 28.75 & 2.26 & 7.4 & 00.0 \\
\hline 11 & 41.29 & 102.99 & 50.41 & 25.50 & 29.00 & 3.00 & 6.8 & 00.0 \\
\hline 12 & 35.19 & 98.00 & 64.23 & 25.50 & 28.50 & 2.58 & 8.6 & 00.0 \\
\hline 13 & 20.79 & 92.40 & 60.23 & 26.50 & 29.00 & 2.63 & 5.9 & 00.0 \\
\hline 14 & 19.77 & 83.78 & 55.03 & 25.50 & 29.00 & 3.52 & 5.8 & 00.0 \\
\hline 15 & 19.33 & 75.78 & 44.98 & 24.35 & 28.00 & 3.80 & 3.7 & 11.0 \\
\hline 16 & 18.26 & 39.20 & 38.78 & 24.00 & 27.00 & 3.50 & 8.8 & 00.0 \\
\hline 17 & 15.31 & 22.44 & 33.89 & 24.50 & 27.50 & 2.45 & 9.2 & 00.0 \\
\hline $\begin{array}{l}\text { Mean } \pm \\
\text { SD }\end{array}$ & $28.31 \pm 15.08$ & $60.76 \pm 30.56$ & $36.98 \pm 15.65$ & $26.18 \pm 1$. & $8.76 \pm 1.2$ & $2.95 \pm 0.64$ & $7.65 \pm 1.57$ & $0.68 \pm 0.97$ \\
\hline
\end{tabular}

N.B Starting date of the algal culture was 3.10.11. Initial cell density of culture on zero day was $0.152 \times 10^{6}$ cells ml $^{-1}$ * Data of sunshine period and rainfall were collected from "Weather Yard", Bangladesh Agricultural University, Mymensingh.

Int. J . Agril. Res. Innov. \& Tech. 4 (2): 6-10, December, 2014 


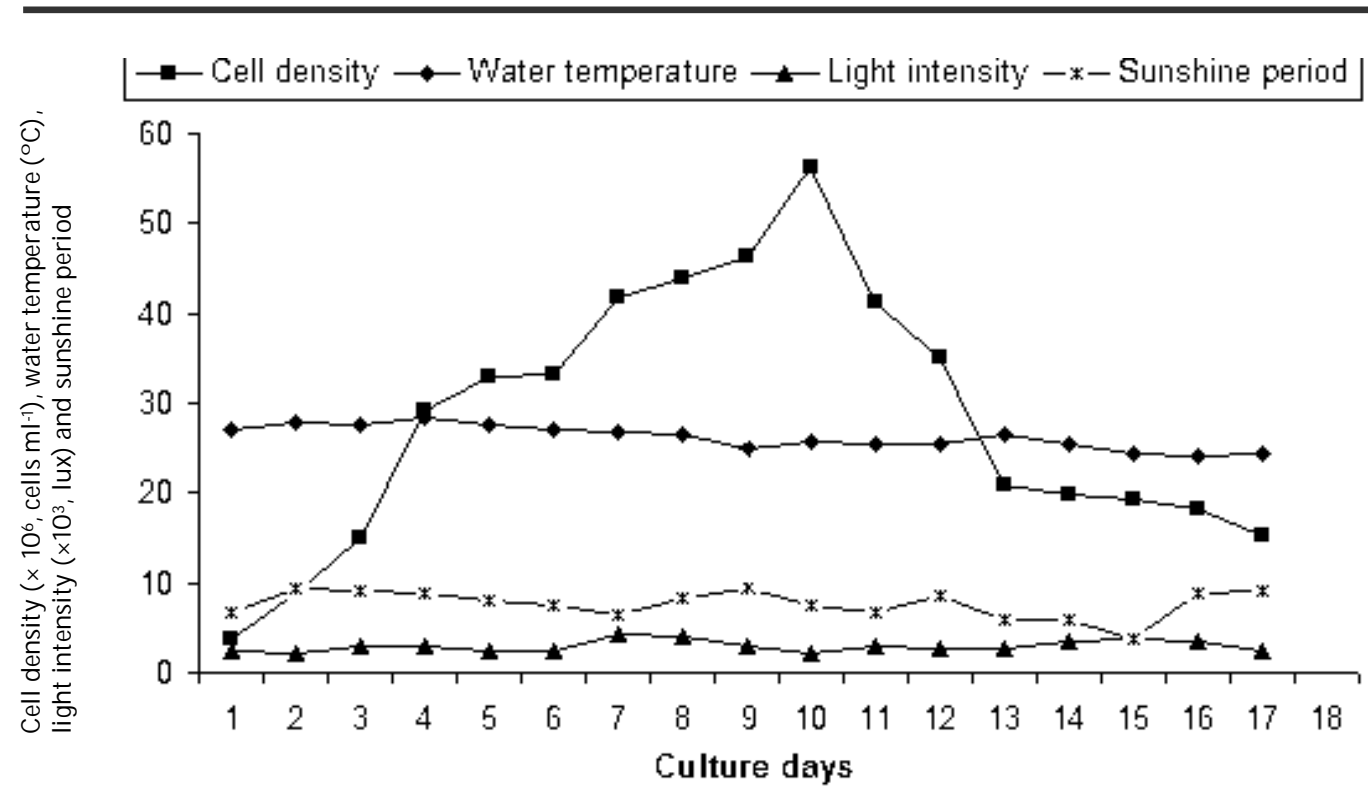

Fig. 1. Daily variations of mean cell density $\left(\times 10^{6}\right.$, cells $\left.\mathrm{ml}^{-1}\right)$ of $\mathrm{C}$. ellipsoidea cultured in medium-I (pulse bran extract, treatment-I) and average water temperature $\left({ }^{\circ} \mathrm{C}\right)$, light intensity $\left(\times 10^{3}\right.$, lux $)$ and sunshine period ( $\mathrm{hrs}$.)

Cell densities of C. ellipsoidea in medium II (soil extract medium)

of $102.99 \times 10^{6}$ cells $\mathrm{ml}^{-1}$ in 11 days. The average density of C. ellipsoidea was $60.76 \times 10^{6}$ cells ml-

The growth of C. ellipsoidea cultured in medium II (soil extract) attained the maximum cell density ${ }^{1}$ after the culture period of 17 days (Table 1, Fig. 2).

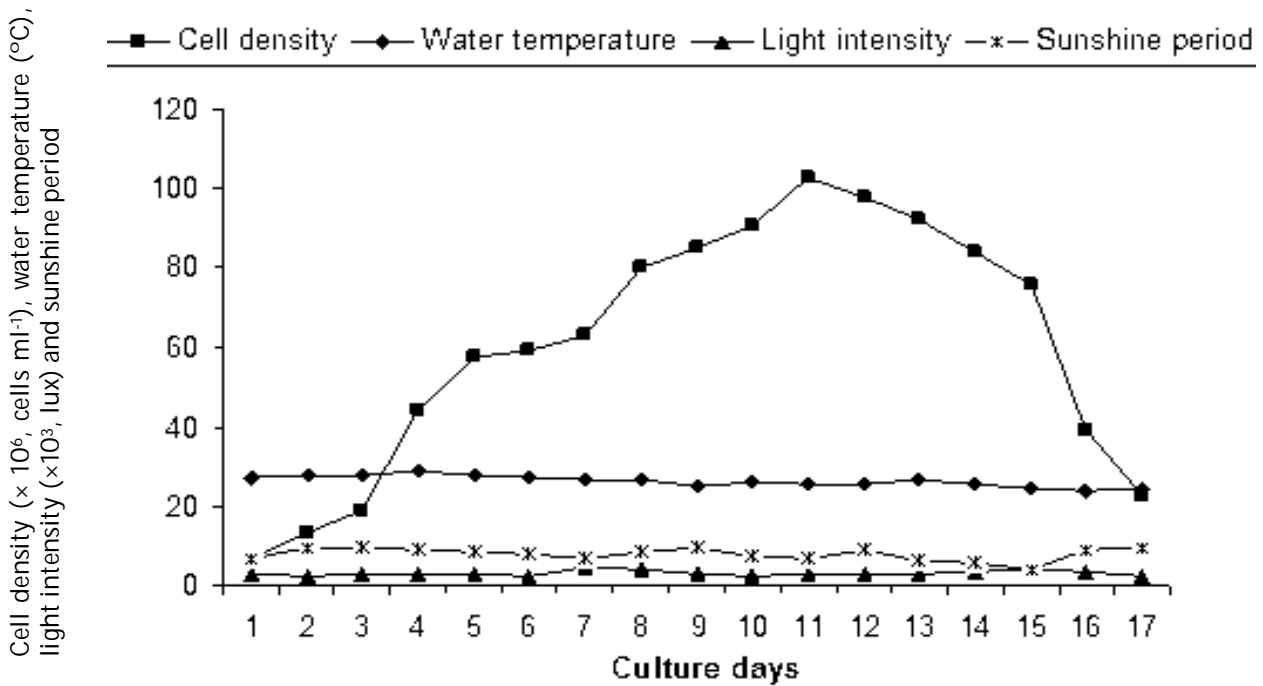

Fig. 2. Daily variation of mean cell density $\left(\times 10^{6}\right.$, cells $\left.\mathrm{ml}^{-1}\right)$ of C. ellipsoidea cultured in medium-II (soil extract, treatment-II) and average water temperature $\left({ }^{\circ} \mathrm{C}\right)$, light intensity $\left(\times 10^{3}\right.$, lux) and sunshine period (hrs.)

Cell densities of $\mathrm{C}$. ellipsoidea in medium III (inorganic medium)

The growth of C. ellipsoidea cultured in medium III (inorganic) attained the maximum cell density of $64.23 \times 10^{6}$ cells ml- $^{-1}$ in 17 days. The average cell density of C. ellipsoidea was $37.17 \times 10^{6}$ cells $\mathrm{ml}^{-1}$ after the culture period of 17 days. (Table 1, Fig. 3). Comparison of daily variations of mean cell density $\left(\mathrm{x}^{1} 0^{6} \mathrm{cell} \mathrm{ml}^{-1}\right)$ of $\mathrm{C}$. ellipsoidea of media I , II, and III have been presented in Fig. 4. 


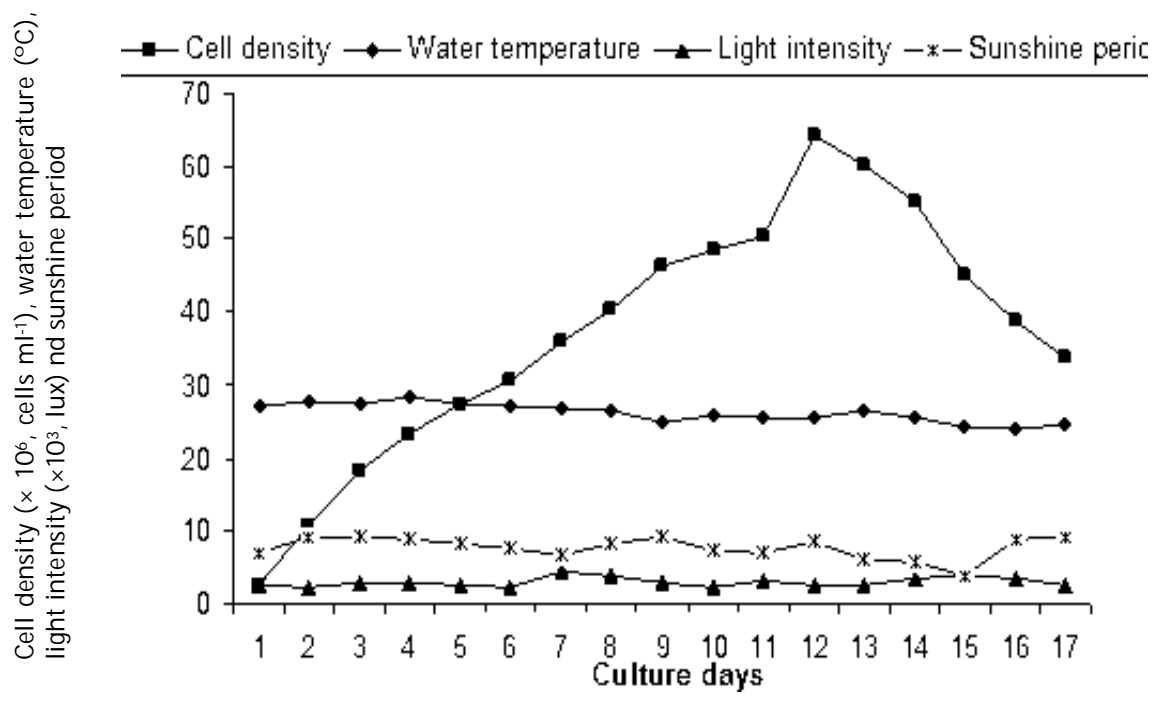

Fig. 3. Daily variation of mean cell density $\left(\times 10^{6}\right.$ cells $\left.\mathrm{ml}^{-1}\right)$ of C. ellipsoidea cultured in medium-III (Inorganic, treatment-III) and average water temperature $\left({ }^{\circ} \mathrm{C}\right)$, light intensity $\left(\times 10^{3}\right.$, lux $)$ and sunshine period (hrs.)

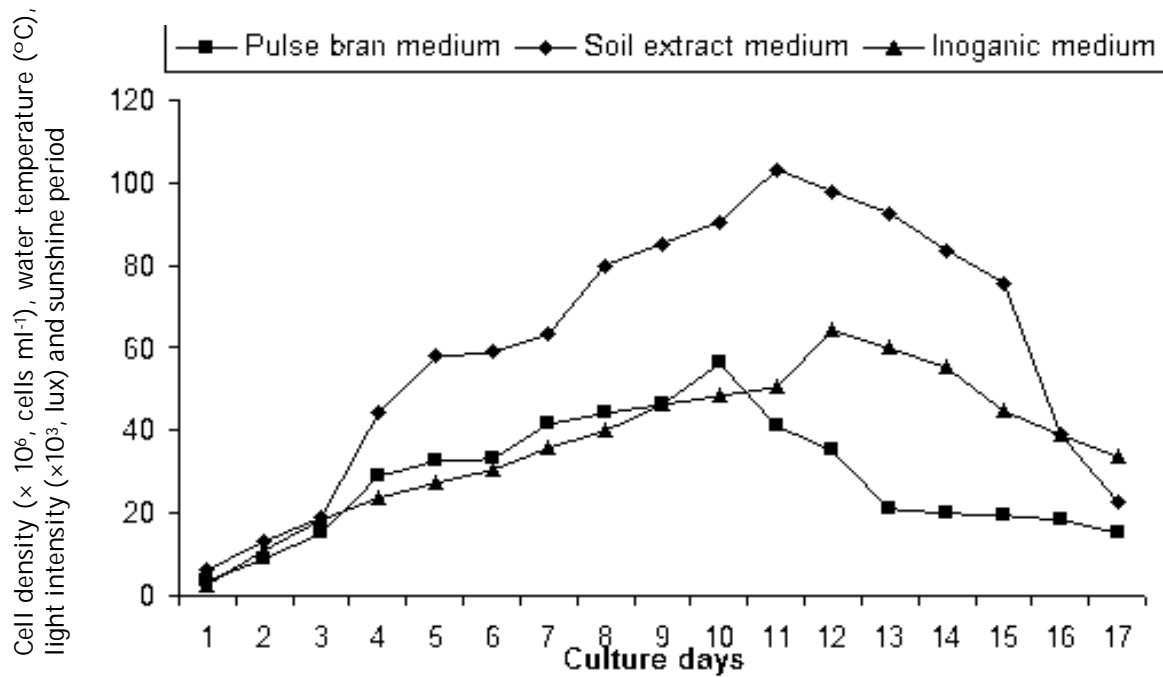

Fig. 4. Comparison of daily variation of mean cell density $\left(\times 10^{6}\right.$ cells $\left.\mathrm{ml}^{-1}\right)$ of $\mathrm{C}$. ellipsoidea cultured in medium-I (pulse bran extract, treatment-I), medium-II (soil extract, treatment-II) and medium-III (inorganic, treatment-III)

Chemical properties of the three cultural media have been presented in Table 2 .

Table 2. Chemical properties of the culture media

\begin{tabular}{lccccc}
\hline Culture medium & $\mathrm{pH}$ & $\begin{array}{c}\text { Free } \mathrm{CO}_{2} \\
(\mathrm{ppm})\end{array}$ & $\begin{array}{c}\text { Total alkalinity } \\
(\mathrm{ppm})\end{array}$ & $\begin{array}{c}\mathrm{NO}_{3}-\mathrm{N} \\
(\mathrm{ppm})\end{array}$ & $\begin{array}{c}\mathrm{PO}_{4}-\mathrm{P} \\
(\mathrm{ppm})\end{array}$ \\
\hline Pulse bran medium & 7.9 & 26 & 220 & 45 & 10.9 \\
Soil extract medium & 7.6 & 9 & 200 & 45 & 15.1 \\
Inorganic medium & 7.5 & 19 & 150 & 133.33 & 37.06 \\
\hline
\end{tabular}

\section{Discussion}

The range of cell density of C. ellipsoidea in medium I (pulse bran extract medium) was 3.68 to $56.32 \times 10^{6}$ cells ml- $^{-1}$ during the culture period. The average cell density was $28.31 \pm 15.084 \times 10^{6}$ cells $\mathrm{ml}^{-1}$. During the culture period of $\mathrm{C}$. ellipsoidea in medium I exponential phase was up to $10^{\text {th }}$ day from the beginning and then from stationary phase cell density started to decline towards death phase. 
The range of cell density of C. ellipsoidea in medium II (soil extract medium) was 6.4 to $102.99 \times 10^{6}$ during the culture period. The average cell density was $60.76 \pm 30.56 \times 10^{6}$ cells $\mathrm{ml}^{-1}$. During the culture period of C. ellipsoidea in medium II, exponential phase was found up to $11^{\text {th }}$ day from the beginning and then from stationary phase cell density started to decline towards death phase.

The range of cell density of $C$. ellipsoidea in medium III (inorganic medium) was 2.56 to $64.23 \times 10^{6}$ cells ml ${ }^{-1}$ during the culture period. The average cell density was $37.17 \pm 16.43 \times 10^{6}$ cells $\mathrm{ml}^{-1}$. During the culture period of $\mathrm{C}$. ellipsoidea in medium III, exponential phase was found up to $12^{\text {th }}$ day from the beginning and then from stationary phase cell density started to decline towards death phase.

Wongsnansilp et al. (2007) found, in an experiment of culture of an alga, Chlorosarcinopsis sp. (PSU/CHL20), the highest cell density of $14.8 \times 10^{6}$ cells ml- ${ }^{-1}$ at $30^{\circ} \mathrm{C}$ on 14 day of culture which have little similarities with those of the present experiment but the highest densities found in the present experiment are much higher than those of Wongsnansilp et al. (2007). Singha (2001) performed an experiment on growth performance of $\mathrm{C}$. vulgaris in different concentrations of sugarcane mill effluent medium (SMEM), press mud medium (PMM) and bold basal medium (BBM). The highest standing crop of $159.00 \times 10^{5}$ cell ml-1 $^{-1}$ resulted from the treatment of 50\% SMEM, $163.25 \times 10^{5}$ cell ml- $^{-1}$ from PMM $\left(1.0 \mathrm{~g} \mathrm{~L}^{-1}\right)$ and $213.043 \times 10^{5} \mathrm{cell} \mathrm{ml}^{-1}$ for all the media. The results of growth performance revealed that the growth of $\mathrm{C}$. vulgaris was significantly higher $(\mathrm{P} \leq 0.01)$ in $\mathrm{PPM}$ at the concentration of $1.0 \mathrm{~g} \mathrm{~L}^{-1}$ than other concentrations of PPM and SMEM.

According to ANOVA and DMRT of cell densities of cultures of C. ellipsoidea under treatments I, II and III, it can be concluded that cell densities under 3 treatments (i.e. 3 media) are significantly different ( $F=39.78)$ and among these 3 treatments, treatment II (soil extract medium) is the best for algal culture than treatment I and treatment III. Preparations of soil extract medium and pulse bran medium are simple and the materials are inexpensive and easily available in Bangladesh. So, the use of inexpensive soil extract and pulse bran as algal culture medium might be used commercially and economically to culture algae, especially Chlorella sp., which can be used as feed for fish fry, poultry, livestock and as human food as live feed or as dried powder form.

\section{References}

Becker, E.W. 1994a. Microalgae, Biotechnology and Microbiology. Published by the Press Syndicate of the University of Cambridge. The Pitt Building, Trumpington, 293p.

Becker, E.W. 1994b. Production and Utilization of the blue-green algae Spirulina in India. Biomass, 4: 105-125.

Christi, Y. 2007. Biodiesel from microalgae. Biotech. Adv. Elesvier, Amsterdam, Netherlands, 25 (3): 294-306.

Geldenhuys, D.J., Walmsley, D.J. and Tofrien, D.J. 1988. Quality of algal material produced on a fertilizer-tap water medium in outdoor plastic enclosed system. Aquaculture, 68: 157-164.

Rahman, M.S. 2000. Mass culture of phytoplankton in inexpensive medium. Final Project Report, BAURES. Bangladesh Agricultural University, Mymensingh, pp. 15-25.

Rydlo, O. 1973. Verwendung einiger Milcroalgen in der praktischen Pharmazie. Pharmazie, 6: 147-149.

Sasson, A. 1997. Microalgal Biotechnologies: Recent developments and prospects for developing countries. Biotech Publication 1/25, pp. $42-76$.

Singha, S.K. 2001. Study on the culture of Chlorella vulgaris in various concentrations of pressmud and sugarcane mill effluent. M.S. thesis, Department of Fisheries Management, Faculty of Fisheries. Bangladesh Agricultural University, Mymensingh. 73p.

Soeder, C.I. 1980. Massive cultivation of microalgae: results and prospects. Hydrobiol. 72: 197-209.

Tang, G. and Suter, P.M. 2011. Vitamin A, nutrition and health values of algae: Spirulina, Chlorella, and Dunaliella. J. Pharm. Nutri. Sci. 1: 111-118.

Wongsnansilp, T., Tansakul, P., Arunyanart, M. 2007. Factors affecting growth and betacarotene content of Chlorosarcinopsis sp. (PSU/CHL20) in batch culture. Kasetsart J . Natural Sci. 41 (1): 153-157. 